\title{
A Heterogeneous Precipitate Based Magnesium Ion Selective Electrode-Its Preparation and Analytical Application
}

\author{
M.SUDHA and J.THAMARAI SELVI* \\ Department of Chemistry, Avinashilingam Institute for Home Science \\ and Higher Education for Women, Coimbatore- 641043, India. \\ ${ }^{*}$ Corresponding author E-mail: thamraj2005@ yahoo.co.in \\ http://dx.doi.org/10.13005/ojc/300343
}

(Received: April 06, 2014; Accepted: May 15, 2014)

\begin{abstract}
A new simple ion-selective electrode poly (vinyl chloride) membrane sensor for $\mathrm{Mg}$ (II) ions based on magnesium Salicylate as a new ionophore has been prepared and studied. The electrode exhibits a good potentiometric response for $\mathrm{Mg}$ (II) ion over a wide concentration range $1.0 \times 10^{-5}$ to $1.0 \times 10^{-1} \mathrm{~N}$ with a slope value of electrode-I was $23 \mathrm{mv} / \mathrm{dec}$ ade and $28 \mathrm{mv} /$ decade for electrode-II. The electrode can be used over 2 months with good reproducibility. The sensor was used as an indicator electrode in a potentiometric titration of Mg (II) ions against EDTA. The sensor was used to determine the $\mathrm{Mg}$ (II) ions in baby food products and spinach.
\end{abstract}

Key words: Ion Selective Electrode, Magnesium, poly (vinyl chloride), Potentiometry.

\section{INTRODUCTION}

Magnesium is essential to almost all life on earth. Magnesium is a heart of the chlorophyll molecule, which plants used to convert the carbon dioxide to glucose. Magnesium is found in enzyme in plants and animals, its speed up the rate which certain changes takes place in the plants and animals. Magnesium is an essential element for humans. Humans take 300 to $400 \mathrm{mg}$ of magnesium for their daily diet. Magnesium mainly used as fireworks and medicinal purpose. Defiency of magnesium develops the yellowish blotches in plant and a person may cause some side effects. Magnesium powder is harmful to the environment. Ion Selective Electrode (ISE) is a membrane electrode that responds selectively to ions in the presence of others. ISE measures the potential of a specific ion in solution.ISE possess a higher degree of selectivity. The potential developed at the membrane is the result of either ion exchange or ion transport process takes place between the membrane and solution.ISE in environment analysis offer several advantages over other methods of analysis. ISE are inexpensive and simple to use and have an extremely wide range of applications. 
Potentiometric measurement is an electro analytical method, which is based on the measurement of potential of an electrode system. It establishes the analyte ion in the presences of various interfering ions from the sample. Potentiometric method provides information about concentration of reactant during the titration.

In this study, a new simple heterogeneous precipitate based magnesium ion selective electrode has been prepared and the electrode potential performance of parameters like slope, response time, measurement range, effect of $\mathrm{pH}$, effect of medium, and selectivity coefficient with respect to different interfering ions have been measured. An attempt was also made to determined magnesium ion in real sample like spinach and baby food products.

\section{Experimental process}

Preparation of Magnesium Salicylate ionophore Magnesium nitrate hexahydrate $(7.01 \mathrm{~g})$ and salicylic acid $(9.501 \mathrm{~g})$ was dissolved in $100 \mathrm{ml}$ of methanol. This reaction mixture was stirred for 30 min with use of magnetic stirrer; the clear solution was obtained. $25 \mathrm{ml}$ of ammonia was added to the solution to get white precipitate, which is filtered and dried for 24 hours. Weight of crude precipitate is $5.95 \mathrm{~g}$ and recrystallised from distilled water.

\section{Preparation Coated Ion selective electrode-I}

Copper wire was polished with fine emery paper and the wire was dipped in to the solution ( $0.3 \mathrm{~g}$ of prepared ionophore (Magnesium Salicylate), polyvinyl chloride, dibutyl phthalate, sodium tetra phenyl borate, and tetra hydro furan) for 24 hours and dried for overnight. The electrode-I was kept in equilibrium for 2 weeks in $1 \mathrm{~N}$ solution of $\mathrm{Mg}\left(\mathrm{NO}_{3}\right)_{2}$. coated copper wire (working electrode)

The electrode system for the measurement can be represented as

$\begin{array}{lcl}\text { Coated copper wire } & \text { Sample } & \begin{array}{l}\text { External } \\ \text { reference } \\ \text { electrode } \\ \text { (working electrode) }\end{array} \\ & \text { solution } & \mathrm{AgCl}\end{array}$

\section{Preparation of Membrane}

$0.4 \mathrm{~g}$ of ionophore with $0.1 \mathrm{~g}$ of polyvinyl chloride, $0.1 \mathrm{~g}$ of sodium tetra phenyl borate, predetermined ratio of dibutyl phthalate and tetra hydro furan are taken and the mixture are allow to heat in a steam bath still evaporate the liquids. The precipitate was mixed with araldite (epoxy adhesive) (Huntsman advanced materials, India, Pvt LTD) to make a homogeneous paste which was then applied on the clean watch glass. The paste was uniformly spread over the watch glass. The membrane was air dried for 48 hours (Electrode -II).

\section{Preparation of Membrane lon selective electrode- II}

A circular piece of this membrane was cut and fixed with resin at one end of the hollow glass tube of diameter $2 \mathrm{~cm}$ and length $8 \mathrm{~cm}$. The tube was filled with saturated solution of $\mathrm{Mg}\left(\mathrm{NO}_{3}\right)_{2}$ and reference copper metal wire of diameter $0.5 \mathrm{~mm}$ and length $20 \mathrm{~cm}$ was inserted through other end of the tube in such a way that it remained dipped in the saturated solution of $\mathrm{Mg}\left(\mathrm{NO}_{3}\right)_{2}$. This complete assembly will work as an ion selective electrode of $\mathrm{Mg}$ (II) ion. This ion selective electrode was kept in $1 \mathrm{~N}$ solution of $\mathrm{Mg}\left(\mathrm{NO}_{3}\right)_{2}$ for one week for equilibrium.

The electrode system for the measurement can be represented as

\begin{tabular}{lllll}
\hline Internal & Internal & Electro & Sample & External \\
\hline Reference & Reference & Active & Solution & Reference \\
Electrode & Solution & Membrane & & Electrode \\
$(\mathrm{Cu}$ wire $)$ & $\left(\mathrm{Mg}\left(\mathrm{NO}_{3}\right)_{2}\right)$ & & & $(\mathrm{Ag} / \mathrm{AgCl})$ \\
& & & & \\
\hline
\end{tabular}

The prepared electrode was connected to one terminal of a digital potentiometer (Equiptronics $E Q-602)$. The other terminal was connected to the reference electrode $(\mathrm{Ag} / \mathrm{AgCl})$. The ISE was immersed in the sample solution of $1 \mathrm{~N} \mathrm{Mg}\left(\mathrm{NO}_{3}\right)$ ${ }_{2}$ and the reference electrode immersed in doubly distilled water. The solutions are connected by using Potassium nitrate - agar salt bridge. 
Preparation of spinach solution

Spinach was dried for 12 hours at $80^{\circ} \mathrm{C}$ in oven and ground well. To $1 \mathrm{~g}$ of powdered spinach $5 \mathrm{ml}$ of concentrated $\mathrm{HNO}_{3}$ and $2 \mathrm{ml}$ of $\mathrm{HClO}_{4}$ were added. The solution digests for 40 minutes to get final volume of $4 \mathrm{ml}$ and add $10 \mathrm{ml}$ water. Filtered the solution in a $100 \mathrm{ml}$ standard flask and diluted with deionized water to the volume (Nikolas et al., 1997).

\section{Preparation of baby food products solution}

$10 \mathrm{~g}$ of baby food and $1 \mathrm{ml}$ of concentrated hydrochloric acid is added and stirred well. This solution transferred to a standard flask and makeup to $100 \mathrm{ml}$ with deionized water. (Seema et al., 1999).

\section{RESULTS AND DISCUSSION}

\section{Characterization}

IR spectrum of ionophore (Magnesium salicylate) In the IR spectrum the peak at $1759 \mathrm{~cm}^{-1}$ corresponding to the carbonyl group frequency and the peak at $1141 \mathrm{~cm}^{-1}$ attributes to the C-O-C group. The peak at $979.84 \mathrm{~cm}^{-1}$ corresponding to the $\mathrm{C}=\mathrm{C}$.

In UV spectrum the peak at $269.32 \mathrm{~nm}$ corresponding to the aromatic region.

A series of aqueous solution of magnesium nitrate of different concentration range from $1 \mathrm{~N}$ to $1 \times 10^{-7}$ were prepared. The electrode potential

Table 1: Electrode response for Electrode-I and Electrode-II

\begin{tabular}{lccc}
\hline S.No & Concentration of $\mathbf{M g}\left(\mathrm{NO}_{3}\right)_{2}$ solution $(\mathrm{N})$ & Electrode-IEMF(Volts) & Electrode-IIEMF(Volts) \\
\hline 1 & 1 & 0.120 & 0.059 \\
2 & $1 \times 10^{-1}$ & 0.133 & 0.049 \\
3 & $1 \times 10^{-2}$ & 0.147 & 0.040 \\
4 & $1 \times 10^{-3}$ & 0.153 & 0.033 \\
5 & $1 \times 10^{-4}$ & 0.163 & 0.027 \\
6 & $1 \times 10^{-5}$ & 0.165 & 0.025 \\
7 & $1 \times 10^{-6}$ & 0.165 & 0.025 \\
\hline
\end{tabular}

Table 2: Effect of pH for Electrode-I

\begin{tabular}{lccc}
\hline S.No & Concentration of $\left(\mathrm{MgNO}_{3}\right)_{2}$ & Electrode-IEMF(Volts) & $\mathrm{pH} 4$ \\
\hline 1 & 1 & 0.120 & 0.120 \\
2 & $1 \times 10^{-1}$ & 0.133 & 0.137 \\
3 & $1 \times 10^{-2}$ & 0.147 & 0.145 \\
4 & $1 \times 10^{-3}$ & 0.153 & 0.148 \\
5 & $1 \times 10^{-4}$ & 0.163 & 0.161 \\
6 & $1 \times 10^{-5}$ & 0.165 & 0.165 \\
\hline
\end{tabular}

Table 3: Effect of pH for Electrode-II

\begin{tabular}{lcccc}
\hline S.No & Concentration of $\left(\mathrm{MgNO}_{3}\right)_{2}$ & Electrode-IIEMF(Volts) & pH 4 & pH 9 \\
\hline 1 & 1 & 0.059 & 0.058 & 0.061 \\
2 & $1 \times 10^{-1}$ & 0.049 & 0.047 & 0.052 \\
3 & $1 \times 10^{-2}$ & 0.040 & 0.044 & 0.045 \\
4 & $1 \times 10^{-3}$ & 0.033 & 0.032 & 0.030 \\
5 & $1 \times 10^{-4}$ & 0.027 & 0.029 & 0.022 \\
6 & $1 \times 10^{-5}$ & 0.025 & 0.026 & 0.021 \\
\hline
\end{tabular}


Table 4: Effect of Medium for $\mathrm{Mg}^{2+}$ Ions

\begin{tabular}{lccc}
\hline Concentration of $\mathbf{M g}\left(\mathrm{NO}_{3}\right)_{2}$ solution (N) & Solvent & Percentage of the solvent & EMF (volts) \\
\hline $1 \mathrm{~N} \mathrm{Mg}\left(\mathrm{NO}_{3}\right)_{2}$ & Ethanol & $25 \%$ & 0.116 \\
& & $50 \%$ & 0.111 \\
& Hexane & $25 \%$ & 0.114 \\
& & $50 \%$ & 0.116 \\
& & $75 \%$ & 0.118 \\
& $\mathrm{THF}$ & $50 \%$ & 0.114 \\
& $\mathrm{DMA}$ & $50 \%$ & 0.111 \\
& $\mathrm{DMF}$ & $25 \%$ & 0.113 \\
& & $50 \%$ & 0.115 \\
\hline
\end{tabular}

Table 5: Effect of Medium for $\mathrm{Mg}^{2+}$ Ions

\begin{tabular}{lccc}
\hline Concentration of $\mathbf{M g}\left(\mathrm{NO}_{3}\right)_{2}$ solution (N) & Solvent & Percentage of the solvent & EMF (volts) \\
\hline $1 \mathrm{~N} \mathrm{Mg}\left(\mathrm{NO}_{3}\right)_{2}$ & Ethanol & $25 \%$ & 0.116 \\
& & $50 \%$ & 0.111 \\
& Hexane & $25 \%$ & 0.114 \\
& & $50 \%$ & 0.116 \\
& & $75 \%$ & 0.118 \\
& $\mathrm{THF}$ & $50 \%$ & 0.114 \\
& $\mathrm{DMA}$ & $50 \%$ & 0.111 \\
& $\mathrm{DMF}$ & $25 \%$ & 0.113 \\
& & $50 \%$ & 0.115 \\
\hline
\end{tabular}

Table 6: Selectivity Coefficient Values for Electrode-I

\begin{tabular}{lcc}
\hline S.No & Cations & Selectivity Coefficient \\
\hline 1 & $\mathrm{NH}_{4}^{+}$ & $8.6 \times 10^{-5}$ \\
2 & $\mathrm{Al}^{3+}$ & $4.3 \times 10^{-5}$ \\
3 & $\mathrm{Na}^{+}$ & $1.7 \times 10^{-4}$ \\
\hline
\end{tabular}

Table 7: Selectivity Coefficient Values for Electrode-II

\begin{tabular}{lcc}
\hline S.No & Cations & Selectivity Coefficient \\
\hline 1 & $\mathrm{NH}_{4}^{+}$ & $-7.1 \times 10^{-5}$ \\
2 & $\mathrm{Al}^{3+}$ & $-1.7 \times 10^{-4}$ \\
3 & $\mathrm{Na}^{+}$ & $-3.5 \times 10^{-5}$ \\
4 & $\mathrm{~K}^{+}$ & $-3.5 \times 10^{-5}$ \\
5 & $\mathrm{Ni}^{2+}$ & $3.5 \times 10^{-5}$ \\
\hline
\end{tabular}

of series of standard solution of $\mathrm{Mg}^{2+}$ ion was measured. For both the electrode (I\&II) the liner response was observed from $1 \mathrm{~N}$ to $1 \times 10^{-5} \mathrm{~N}$. The values are tabulated in table1. The calibration curve was plotted using best fit method.

The slope value was calculated from the calibration curve and it was found to be $23 \mathrm{mv} /$ decade for electrode-I and 28mv/decade for Electrode-II.

\section{Effect of pH for Electrode-I and Electrode-II}

The effect of $\mathrm{pH}$ on the response of electrode (I\&II) was studied in this work. It was found that electrode-I worked well in the acidic $\mathrm{pH}$ range of 4.0 in the concentration of $1 \times 10^{-5} \mathrm{~N} \mathrm{Mg}$ (II) ions. The electrode-Il worked well in acidic $\mathrm{pH}$ range of 4.0 in the concentration range of $1 \times 10^{-5} \mathrm{~N} \mathrm{Mg}(\mathrm{II})$ ions and $\mathrm{pH}$ range of 9.18 it worked well in the concentration of $1 \times 10^{-3} \mathrm{~N} \mathrm{Mg}$ (II) ions. The values are tabulated in table 2 \&3. 
Table 8: Magnesium determination in some real samples for Electrode I

\begin{tabular}{|c|c|c|c|c|}
\hline S.No & Theoretical value (mg) & Sample & Result obtainedBy ISE (mg) & Recovery \\
\hline 1 & 16.5 & Horlicks (Blue) & 16.4 & $99 \%$ \\
\hline 2 & 65 & Boost (Pink) & 65.36 & $96 \%$ \\
\hline 3 & 79 & Spinach (Brown) & 79.54 & $99 \%$ \\
\hline S.No & Theoretical Value (mg) & Sample & Result obtainedBy ISE (mg) & Recovery \\
\hline 1 & 16.5 & Horlicks (Blue) & 17.6 & $94 \%$ \\
\hline 2 & 65 & Boost (Pink) & 60.20 & $95.5 \%$ \\
\hline 3 & 79 & Spinach (Brown) & 73.21 & $93 \%$ \\
\hline
\end{tabular}

\section{Effect of Medium}

The effect of medium on the response of electrode (I\&II) also be done. For a electrode-I was found that the potential remains unchanged with a standard solution of $1 \mathrm{~N} \mathrm{Mg}\left(\mathrm{NO}_{3}\right)_{2}$ in a series of hexane $(25 \%, 50 \%, 75 \%)$, ethanol( $25 \%, 50 \%)$, DMF $(25 \%, 50 \%), \operatorname{THF}(50 \%)$ and $\operatorname{DMA}(50 \%)$.For electrode-II was found that the potential remains unchanged with a standard solution of $1 \mathrm{~N} \mathrm{Mg}\left(\mathrm{NO}_{3}\right)_{2}$ in a series of hexane $(25 \%, 50 \%, 75 \%)$, DMA (25\%,50\%, 75\%), ethanol(25\%,50\%, 75\%), THF $(25 \%, 75 \%)$ and $\operatorname{DMF}(25 \%, 50 \%)$. The values are tabulated in table $4 \& 5$.

\section{Selectivity of Electrode-I and Electrode-II}

Selectivity is one of the most important characteristics of a chemical sensor. The potential response of the magnesium ion selective electrode (I\&II) to different metal ion have been investigated by determining the selectivity coefficient of the electrodes using fixed interference method (FIM) based on the semi empirical Nicolskii-Eisenman equation and the concentration of interfering ion was set to $1 \mathrm{~N}$. It was found that the potential remains unaffected in the presence of a series of various cation.

Interference by cations for Electrode-I and Electrode-II

To study the cationic interference due to other ions, the electrode potential were recorded in a mixed solution method having a fixed $1 \mathrm{~N}$ concentration of primary ion $\left(\mathrm{Mg}^{2+}\right)$ and interference ions. For the electrode-I from the interference study the potential remains unaffected in the presence of

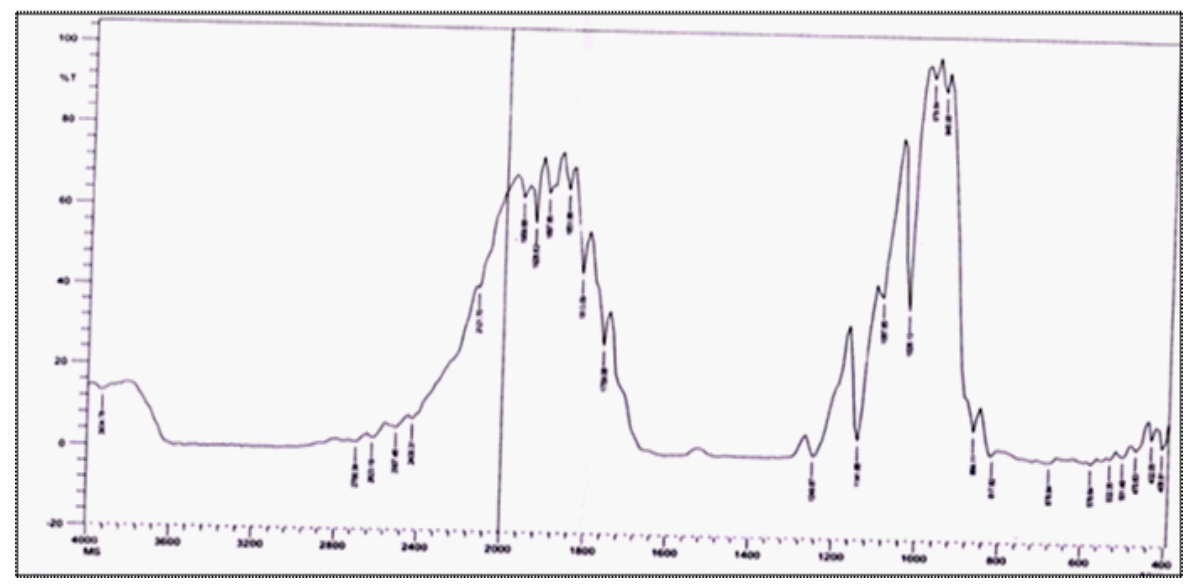

Fig. 1: IR Spectrum of Magnesium Salicylate 


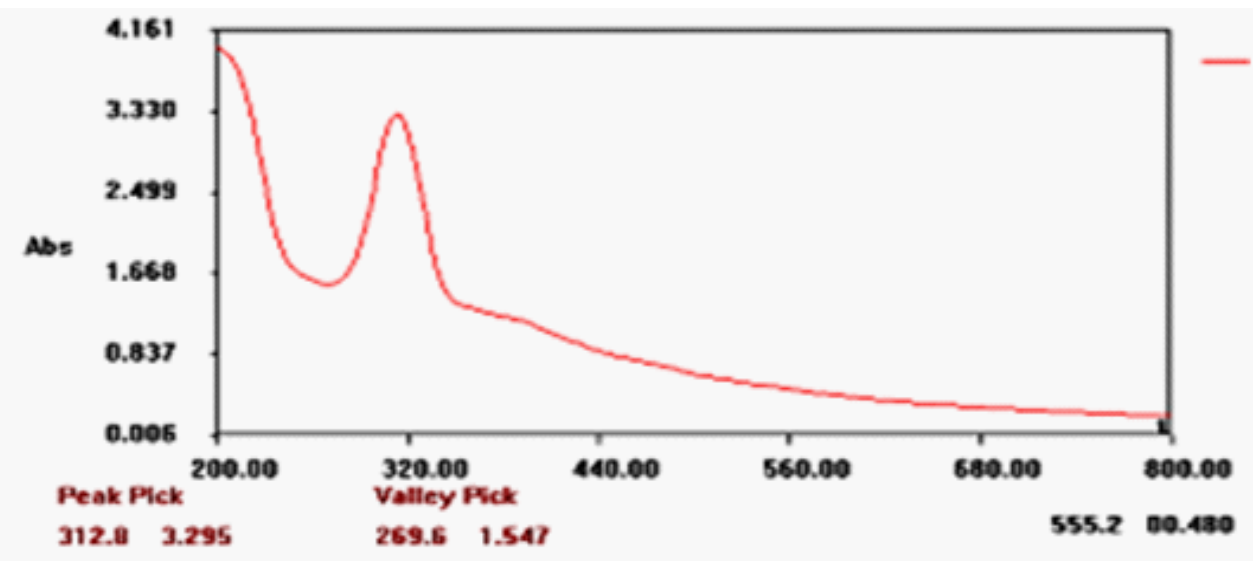

Fig. 2: UV spectrum of Magnesium Salicylate

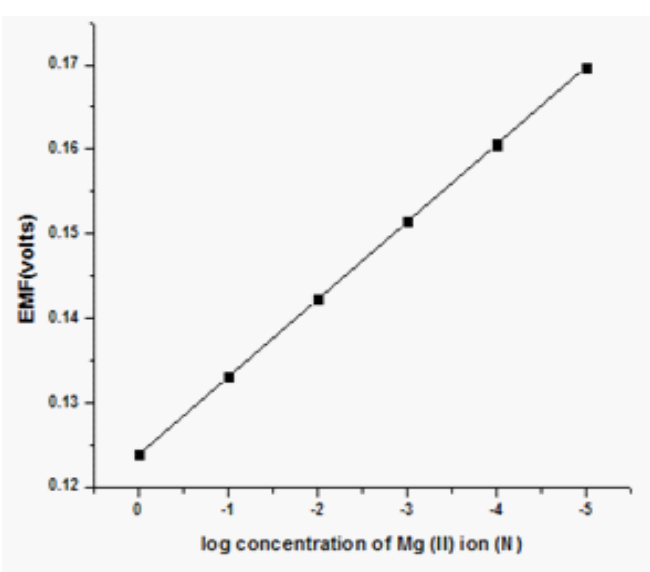

Fig. 3: Plot of log concentration of Mg(II) ion (M) Vs EMF (volts)

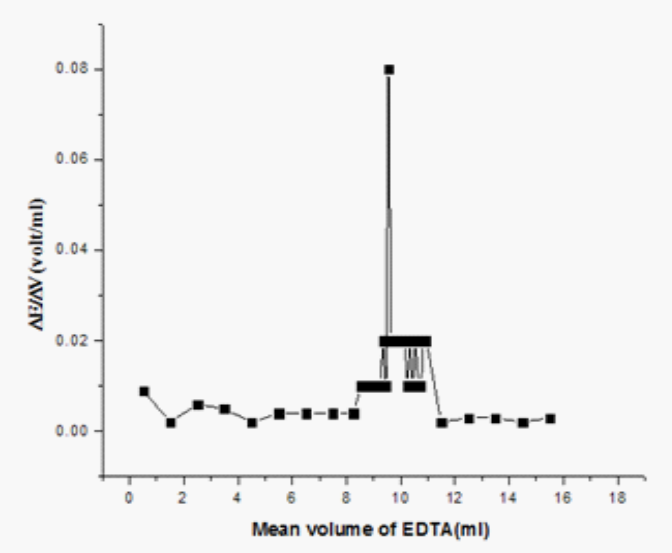

Fig. 5: Plot of mean volume of EDTA (ml) Vs $\Delta E / \Delta V$ (volt $/ \mathrm{ml})$

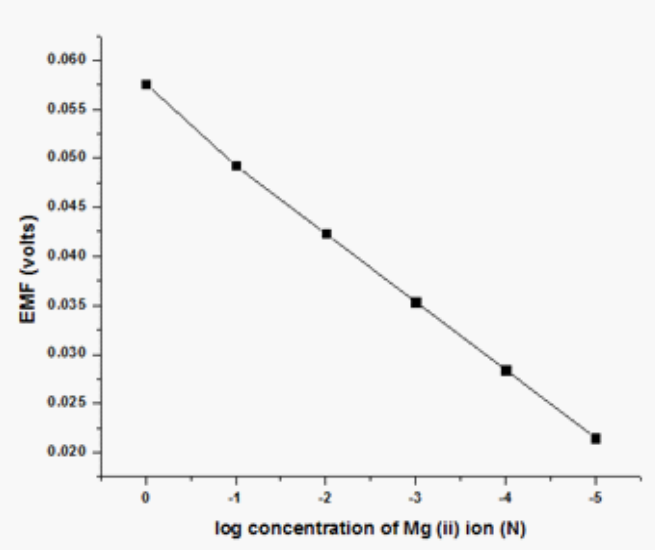

Fig. 4: Plot of log concentration of $\mathrm{Mg}(\mathrm{II})$ ion (M) Vs EMF (volts)

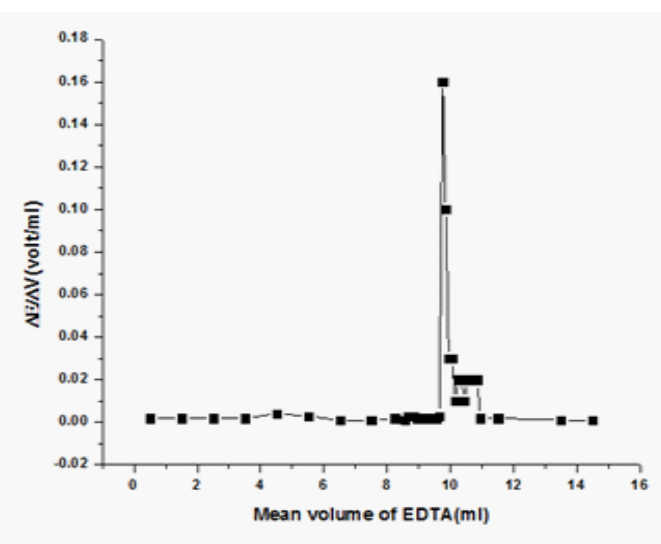

Fig. 6: Plot of mean volume of EDTA (ml) Vs $\Delta E / \Delta V$ (volt/ml) 


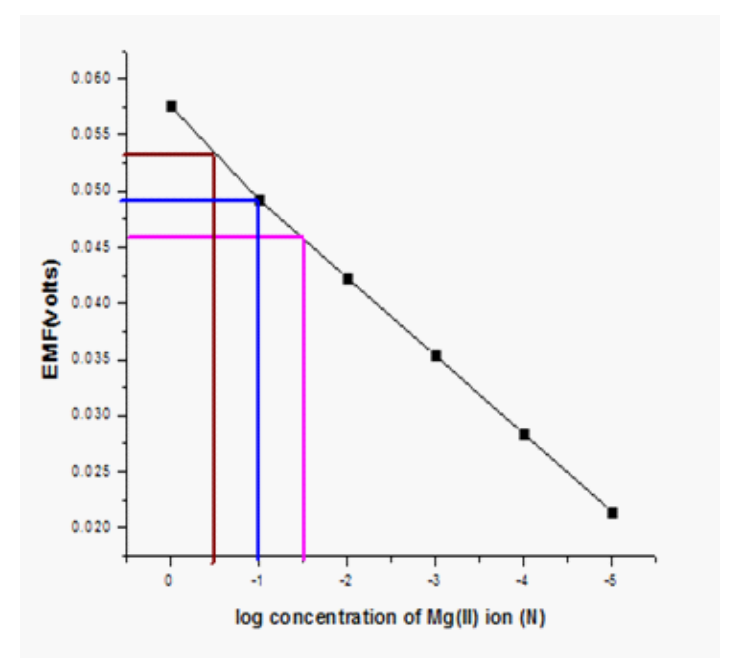

Fig. 7: Plot of log concentration of $\mathrm{Mg}(\mathrm{II})$ ion (N) Vs EMF (volts)

series of various cations like $\mathrm{NH}_{4}^{+}, \mathrm{Al}^{3+}$, and $\mathrm{Na}^{+}$. For a electrode-Il the potential remains unaffected in the presence of series of various cations like $\mathrm{NH}_{4}^{+}, \mathrm{Al}^{3+}$, $\mathrm{Ni}^{2+}, \mathrm{Na}^{+}$, and $\mathrm{K}^{+}$. The values are tabulated in table $6 \& 7$.

\section{Analytical Application}

The practical application ofproposed two electrodes was tested by using as an indicator electrode for potentiometric titrations of magnesium (II) ion with EDTA solution. To assess the applicability of the sensors to real sample an attempt was made to determine magnesium ion in baby food products (Horlicks, Boost) and spinach. The recovery of magnesium ion in sample analysis was formed to be quantitative with the recovery of magnesium ion was found to be $99 \%, 96 \%, 99 \%$ for electrode-I and electrode-II was found to be $94 \%, 95.5 \%, 93 \%$ of

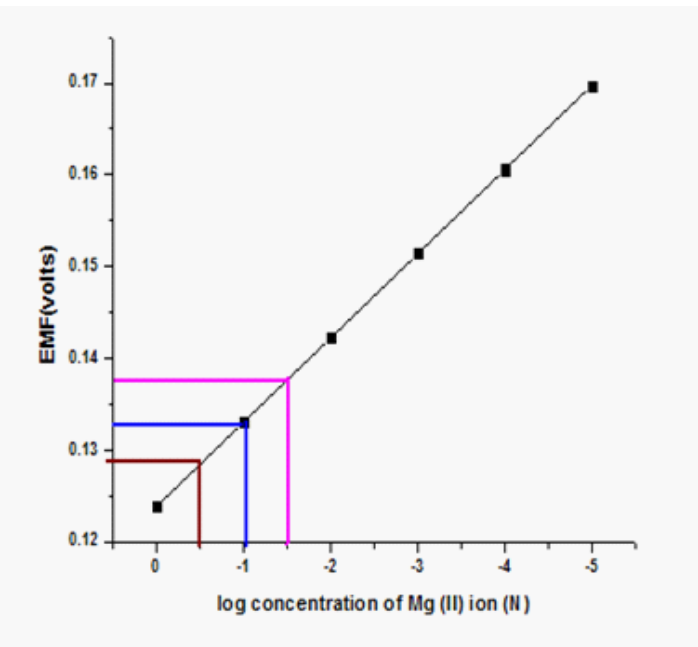

Fig. 8: Plot of log concentration of $\mathrm{Mg}(\mathrm{II})$ ion (N) Vs EMF (volts)

magnesium ion. The values are tabulated in table $8 \& 9$.

\section{CONCLUSION}

A new simple method to determine the magnesium ion developed electrochemically. The proposed two electrodes were found to work well under the laboratory condition. This method is done by Potentiometry; it is accurate, simple and cost effective. The sensor exhibits a Nernstain response in the concentration range $1 \times 10^{-5}$ for both the electrodes (I\&II). The effect of medium, effect of $\mathrm{pH}$, selectivity and response time also measured. The magnesium (II) ion selective membrane sensor effectively applied for the determination of magnesium ion in baby food products and spinach.

\section{REFERENCES}

1. Baniwal,S.; Chandra ,S.; Panwar, A.; Singh,A.K.; Talanta, 1999, 50, 499-508.

2. Chaniotakis, N.A.; Tsagatakis,J.K.; Moschou,E.A.; West,S.J.; Wen,X.; Analytica Chimica Acta, 1999, 356, 105-111.

3. Gupta,V.K.; Chandra, S.; Mangla ,R.; Sensor and Actuators,2002, 86, 235-241.

4. http://bestpractice.bmj.com/best-practice/ monograph/1137.html

5. http://www.iherblibrary.com/magnesiumbook/magnesium-overview

6. WWW.Google.Com 